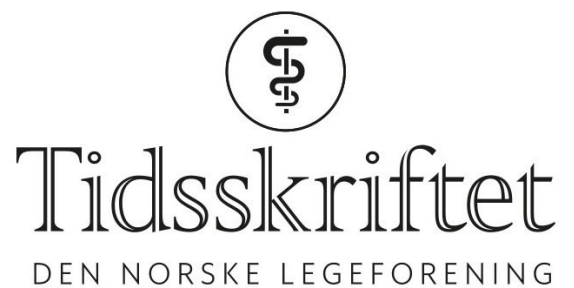

DEN NORSKE LEGEFORENING

\title{
Seksuelle overgrep angår oss alle
}

LEDER

\section{HENRIETTE MYHRE WAITZ}

E-post: henriette-myhre.waitz@hel.oslo.kommune.no

Henriette Myhre Waitz er seksjonsoverlege ved Overgrepsmottaket i Oslo.

Forfatteren har fylt ut ICMJE-skjemaet og oppgir ingen interessekonflikter.

\section{ELINE THORLEIFSSON}

Eline Thorleifsson er overlege ved Overgrepsmottaket i Oslo.

Forfatteren har fylt ut ICMJE-skjemaet og oppgir ingen interessekonflikter.

De fleste leger vil møte pasienter som har vært utsatt for overgrep og vold - og som aldri har fortalt noen om det.

Én av tre kvinner på verdensbasis utsettes for fysisk og/eller seksuell vold fra en partner eller seksuell vold fra en ikke-partner (1). Seksuelle overgrep og kjønnsbasert vold er et globalt folkehelseproblem og for kvinner i fertil alder utgjør det en høyere risiko for uhelse enn røyking, overvekt og hypertensjon til sammen (2). Voldtekt er et brudd på grunnleggende menneskerettigheter (3). Når det brukes som våpen i krig, regnes det som en forbrytelse mot menneskeheten (4). Et seksuelt overgrep er en krenkelse av det aller mest intime og en ensom opplevelse fordi det er forbundet med skam. Normale etterreaksjoner er en direkte årsak til at mange ikke forteller noen om opplevelsen eller oppsøker hjelp på et tidlig stadium.

Seksuelle overgrep er et samfunnsproblem og ikke bare et individuelt problem. Overgrep har ringvirkninger for langt flere enn dem som selv blir utsatt. Familie, venner og folks opplevelse av trygghet i samfunnet blir påvirket (1). Helsekonsekvensene og kostnadene er store. Traumers effekt på fysisk og psykisk helse samt livskvalitet er veldokumentert (2), og tidlig intervensjon som reduserer risiko for kroniske plager kan være avgjørende (5).

Nær én av ti kvinner i Norge opplyser å ha vært utsatt for voldtekt i løpet av livet, halvparten før fylte 18 år (6). Mange kvinner hemmes i sin livsutfoldelse av frykt for å bli utsatt for et seksuelt overgrep. Personer av alle kjønn utsettes for partnervold, men kvinnene utsettes for den mest alvorlige volden og flest partnerdrap $(1,6)$. Kjønnsperspektivet ved seksuelle overgrep og relasjonsvold kan dermed ikke underkjennes. Samtidig opplyser $1 \%$ av norske menn at de har vært utsatt for voldtekt i løpet av livet (6). Hver enkelt av disse mennene og de transkjønnede skal selvsagt få samme oppmerksomhet, helsehjelp og oppfølging i rettsapparatet som kvinnene.

Nær én av ti kvinner i Norge opplyser å ha vært utsatt for voldtekt i løpet av livet, halvparten før fylte 18 år

Norges 24 døgnåpne overgrepsmottak tilbyr lavterskel helsetjenester som kan benyttes 
uten henvisning og uavhengig av politianmeldelse. Noen mottak er organisert på legevakt, andre på sykehus. Alle undersøkelser foregår frivillig og er gratis. Pasienten ivaretas psykososialt og somatisk, som oftest av tverrfaglige team. Det tilbys også rettsmedisinsk undersøkelse med sporsikring og dokumentasjon av skader i tilfelle pasienten på et tidspunkt ønsker å anmelde (5). Seksuelle overgrep er alvorlige, straffbare handlinger. Politiets og rettsapparatets arbeid er viktig ikke bare for den enkelte anmeldte sak, men også for vårt samfunnsvern. Det rettsmedisinske arbeidet som utføres på blant annet overgrepsmottakene, kan ofte være avgjørende for rettssikkerheten i disse sakene. Rettsmedisinske tjenester som er lett tilgjengelige og av høy kvalitet, er derfor nøkkelfaktorer.

Det er fortsatt behov for en betydelig satsing på overgrepsmottakene faglig og ressursmessig, slik at man får et likeverdig tilbud i hele landet. Både fra et helsemessig og et rettslig perspektiv bekymrer det oss at flertallet ikke søker helsehjelp på et tidlig stadium. Norske tall fra 2014 viste at kun $11 \%$ av kvinnene som hadde vært utsatt for voldtekt, søkte helsehjelp akutt (6). Én av tre forteller aldri noen om overgrepet.

Antall henvendelser til de fleste overgrepsmottak i Norge øker. Dette er en ønsket utvikling, så lenge det er uttrykk for en redusert terskel for å søke hjelp. På Overgrepsmottaket i Oslo har vi hatt $40 \% \emptyset \mathrm{kning}$ i antall henvendelser de siste fem årene og behandler nå i overkant av 6 oo pasienter årlig. Her tilbys tverrfaglig oppfølging i en tre måneders periode. Selv om mange har betydelige plager den første tiden, ser vi heldigvis hvordan de fleste mot slutten av oppfølgingen opplever bedring og gjenvinner kontroll over hverdagen.

Vår erfaring er at det kan ha blitt brukt mye helseressurser på enkelte pasienter uten at noen har spurt dem om det kan ligge et traume bak plagene. Overgrepsmottakene har selv en jobb å gjøre for å senke terskelen og å gjøre tilbudet bedre kjent. Det er likevel enhver leges ansvar å tenke tanken om overgrep og å spørre pasienten om det. Det kan bli en viktig samtale.

\section{LITTERATUR:}

1. Global and regional estimates of violence against women. Prevalence and health effects of intimate partner violence and non-partner sexual violence. Genève: WHO, 2013. https://www.who.int/reproductivehealth/publications/violence/9789241564625/en/ Lest 26.02.2020.

2. Garcia-Moreno C, Watts C. Violence against women: an urgent public health priority. Bulletin of the World Health Organization 2011; 89: 2-2. https://www.who.int/bulletin/volumes/89/1/10-085217/en/ Lest 3.3.2020.

3. FNs verdenserklæring om menneskerettigheter.

https://www.fn.no/Om-FN/Avtaler/Menneskerettigheter/FNs-verdenserklaering-om-menneskerettighe ter Lest 3.3.2020.

4. Roma-vedtektene om Den internasjonale straffedomstol. Forbrytelser mot menneskeheten, artikkel 7. https://lovdata.no/dokument/TRAKTAT/traktat/1998-07-17-2. Lest 26.2.2020.

5. Overgrepsmottak. Veileder for helsetjenesten. IS-1457. Oslo: Sosial- og helsedirektoratet, 2007.

6. Thoresen S, Hjelmdal OK. Vold og voldtekt i Norge: en nasjonal forekomststudie av vold i et livsløpsperspektiv. Rapport nr. 1/2014. Oslo: Nasjonalt kunnskapssenter om vold og traumatisk stress, 2014.

https://www.nkvts.no/rapport/vold-og-voldtekt-i-norge-en-nasjonal-forekomststudie-av-vold-i-et-livslo psperspektiv/ Lest 3.3.2020.

Publisert: 8. mars 2020. Tidsskr Nor Legeforen. DOI: 10.4045/tidsskr.20.0183

(C) Tidsskrift for Den norske legeforening 2020. Lastet ned fra tidsskriftet.no 